\title{
Preoperative $\mu$-opioid receptor availability predicts weight loss following bariatric surgery
}

Henry K. Karlsson ${ }^{1}$, Lauri Tuominen ${ }^{1,2}$, Semi Helin ${ }^{1}$, Paulina Salminen ${ }^{3}$, Pirjo Nuutila ${ }^{1,4}$ and Lauri Nummenmaa ${ }^{1,5}$

1Turku PET Centre, University of Turku, Turku, Finland

2Institute of Mental Health Research, University of Ottawa, Ottawa, Ontario, Canada

${ }^{3}$ Department of Digestive Surgery, University of Turku and Turku University Hospital, Turku, Finland

${ }^{4}$ Department of Endocrinology, Turku University Hospital, Turku, Finland

5Department of Psychology, University of Turku, Turku, Finland

Correspondence to:

Dr. Henry Karlsson

Turku PET Centre

c/o Turku University Hospital

Kiinamyllynkatu 4-8

FI-20520 Turku

Finland

Key words: Obesity; positron emission tomography; reward; opioid; dopamine; receptors; bariatric surgery; weight loss

Conflict of interest

The authors declare no competing financial interests.

Author contributions

HK: Acquired and analyzed PET data, wrote the manuscript

LT: Analyzed PET data, wrote the manuscript

$\mathrm{SH}$ : Produced the radiotracers, wrote the manuscript

PS: Recruited the study subjects, wrote the manuscript

PN: Designed the experiments, wrote the manuscript

$\mathrm{LN}$ : Designed the experiments, wrote the manuscript

\section{Acknowledgments}

The study was conducted within the Finnish Centre of Excellence in Cardiovascular and Metabolic Diseases supported by the Academy of Finland (grants \#251125, \#121031, \#304385), Sigrid Juselius Foundation, University of Turku, Turku University Hospital and Åbo Akademi University. HKK was supported by personal grants from The Finnish Diabetes Research Foundation and The National Graduate School of Clinical Investigation. The funders had no role in study design, data collection and analysis, decision to publish, or preparation of the manuscript. The authors thank the staff of the Turku PET Centre for assistance in the PET imaging. Special thanks goes to research nurse Mia Koutu. 
medRxiv preprint doi: https://doi.org/10.1101/2021.01.27.21250121; this version posted January $31,2021$. The copyright holder for this preprint (which was not certified by peer review) is the author/funder, who has granted medRxiv a license to display the preprint in

Abstract

Background: Bariatric surgery is the most effective method for weight loss in morbid obesity. There is significant individual variability in the weight loss outcomes, yet factors leading to postoperative weight loss or weight regain remain elusive. Alterations in the $\mu$-opioid receptor (MOR) and dopamine $D_{2}$ receptor $\left(D_{2} R\right)$ systems are associated with obesity, appetite control, and reward processing. The magnitude of initial brain receptor system perturbation is a plausible predictor of long-term surgical weight loss outcomes. The aim was to test this hypothesis by measuring obese subjects' $M O R$ and $D_{2} R$ availability with positron emission tomography (PET) preoperatively before bariatric surgery and then assessing their weight development association with regional MOR and $\mathrm{D}_{2} \mathrm{R}$ availabilities at 2-year follow-up.

Methods: We studied 19 morbidly obese women (mean BMI 40, mean age 43) scheduled to undergo bariatric surgery, i.e. Roux-en-Y gastric bypass or sleeve gastrectomy, according to their standard clinical treatment. Preoperative MOR and $D_{2} R$ availabilities were measured using PET with $\left[{ }^{11} \mathrm{C}\right]$ carfentanil and $\left[{ }^{11} \mathrm{C}\right]$ raclopride, respectively. Subject weight was recorded at 3, 6, 12, and 24 months after surgery. Radiotracer binding potentials $\left(B P_{\mathrm{ND}}\right)$ were extracted and correlated with patient weight at different time points. ROls were delineated in the striatum and in limbic and paralimbic components of the emotion and reward networks.

Results: MOR availabilities were not correlated with preoperative weight. MOR availabilities in the amygdala $(r=-0.54)$, insula $(r=-0.46)$, ventral striatum $(r=-0.48)$ and putamen $(r=-0.49)$ were associated with subject weight at 3 months. Significant association was found in the amygdala at 6 months $(r=-0.53), 12(r=-0.49)$, and 24 months $(r=-0.50) . D_{2} R$ availabilities were associated with neither preoperative weight nor weight loss at any follow-up time point.

Conclusions: To our knowledge, this is the first study to demonstrate that neuroreceptor markers prior to bariatric surgery in patients with morbid obesity are associated with the postoperative weight loss. Preoperative MOR availability in the amygdala was associated with long-term postoperative weight development after surgery suggesting that postoperative weight regain may derive from dysfunction in the opioid system. Postoperative weight loss outcomes after bariatric surgery may be partially predicted based on preoperative receptor availability opening up new potential for treatment possibilities.

Clinical Trials Registration: SleevePET2, NCT01373892, http://www.clinicaltrials.gov 
medRxiv preprint doi: https://doi.org/10.1101/2021.01.27.21250121; this version posted January $31,2021$. The copyright holder for this preprint (which was not certified by peer review) is the author/funder, who has granted medRxiv a license to display the preprint in perpetuity.

\section{Introduction}

The prevalence of obesity is constantly increasing and reaching global pandemic levels. Accumulating evidence suggests that dysfunctions in appetite control and reward processing mechanism significantly contribute to weight gain and maintenance, and particularly brain's dopamine and opioid systems in the reward circuit are dysfunctional in obesity. Dopamine $D_{2}$ receptor $\left(D_{2} R\right)$ expression and function are altered in obesity (Volkow et al., 2008; Stice et al., 2011; Salamone and Correa, 2013), whereas endogenous opioid system is consistently linked to hedonic aspects of feeding in animals (Pecina and Smith, 2010; Fields and Margolis, 2015). In humans, feeding triggers endogenous opioid release (Tuulari et al., 2017) and accordingly pharmacological challenge studies have found that both $\mu$-opioid receptor (MOR) antagonists and inverse agonists reduce human eating behaviour (Nathan et al., 2012; Cambridge et al., 2013). MOR levels are also downregulated in obese subjects, underlining the importance the opioid system perturbation in overeating (Burghardt et al., 2015; Karlsson et al., 2015).

Bariatric surgery is currently the most effective method for weight loss in obesity. Mean postoperative total weight loss of $27 \%$ has been shown among patients even after 12 years (Adams et al., 2017). Bariatric surgery procedures are also much more effective than intensive medical therapy to reach glycemic control (Schauer et al., 2017). For weight loss, there is currently some consensus to use standardized reporting guidelines in bariatric surgery literature (Brethauer et al., 2015), but similar uniform consensus needs to be achieved regarding postoperative weight regain in order to assess the durability of weight loss and to reliably evaluate potential treatment options (Salminen, 2018). Weight regain following bariatric surgery occurs in one fifth (Shantavasinkul et al., 2016; Courcoulas et al., 2018; Baig et al., 2019) up to one third of the patients (Cooper et al., 2015; Monaco-Ferreira and Leandro-Merhi, 2017; Voorwinde et al., 2020).

Factors leading to weight regain following surgery remain poorly understood, yet cross-sectional studies point towards a possible role of the brain in regulating the treatment response. Impulsivity and disinhibition are traits often associated with poorer weight loss after surgery, but both psychosocial issues and psychiatric comorbidities may also have a major impact on weight loss outcomes (Odom et al., 2010; Mauro et al., 2019; Muller et al., 2019; Sarwer et al., 2019). However, only few neuroimaging studies have examined neural predictors of weight loss after surgery. To our knowledge, there are only two small MRI studies that have investigated brain markers that might affect the weight loss outcome of the surgery. Functional connectivity and alterations in brain activity in some of the key areas of reward circuit predicted weight loss 12 months after sleeve gastrectomy (Holsen et al., 2018; Cerit et al., 2019). However, the role of specific neurotransmitter systems - such as $D_{2} R$ and MOR implicated in feeding and reward processing - on post-surgical weigh gain and loss remain unknown. In the present study, we addressed this issue by measuring obese subjects' MOR 
medRxiv preprint doi: https://doi.org/10.1101/2021.01.27.21250121; this version posted January $31,2021$. The copyright holder for this preprint (which was not certified by peer review) is the author/funder, who has granted medRxiv a license to display the preprint in

and $D_{2} R$ availability with positron emission tomography (PET) before they underwent bariatric surgery. We followed the subjects for two years and predicted their weight loss outcomes with regional MOR and $D_{2} R$ availabilities. We show that MOR availability particularly in the amygdala predicts long-term outcome of the bariatric surgery, suggesting a causal role of this region in appetite control and food intake.

\section{Methods}

The study was conducted in accordance with the Declaration of Helsinki and approved by the Ethical Committee of the Hospital District of South-Western Finland (SleevePET2, NCT01373892, http://www.clinicaltrials.gov). All participants signed ethical committee-approved, informed consent form prior to scans. Group differences in receptor availabilities between normal-weight and morbidly obese subjects have been previously reported for a subset of the subjects (Karlsson et al., 2015; Karlsson et al., 2016).

\section{Participants}

We studied 19 morbidly obese women (mean BMI 40, mean age 43) scheduled to undergo bariatric surgery, i.e. Roux-en-Y gastric bypass or sleeve gastrectomy, according to their standard clinical treatment. Subject characteristics are shown in the Table 1. Clinical screening of the subjects included history, physical examination, anthropometric measurements, and laboratory tests. Exclusion criteria for this study involved opiate drug use, neurological and severe mental disorders, substance abuse, and excessive alcohol consumption determined by clinical interviews, medical history, and blood tests. Seven subjects were smokers (3-15 cigarettes per day). Antidiabetic, antihypertensive and cholesterol lowering drugs were paused prior to the study. Subject weight was recorded before surgery as well as at 3, 6, 12, and 24 months after surgery during a standard hospital visit. Two subjects dropped out of the study before 24 months follow-up visit, but their weight data at 3,6, and 12 months were included in the analysis. Baseline depressive and anxiety symptoms were recorded using Beck Depression Index II (BDI-II) and State-Trait Anxiety Inventory (STAI), respectively (Spielberger et al., 1983; Beck et al., 1996). 
medRxiv preprint doi: https://doi.org/10.1101/2021.01.27.21250121; this version posted January $31,2021$. The copyright holder for this preprint (which was not certified by peer review) is the author/funder, who has granted medRxiv a license to display the preprint in

Table 1: Characteristics of the participants $(N=19)$. Data are presented as mean $\pm S D$.

\begin{tabular}{|l|l|}
\hline Age $(\mathrm{y})$ & $43.3 \pm 8.2$ \\
\hline Preoperative weight $(\mathrm{kg})$ & $109.8 \pm 12,8$ \\
\hline Height $(\mathrm{cm})$ & $164.5 \pm 5.0$ \\
\hline BMI $\left(\mathrm{kg} / \mathrm{m}^{2}\right)$ & $40.4 \pm 4.1$ \\
\hline Amount of alcohol use (units per week) & $1.5 \pm 1.7$ \\
\hline Tobacco smokers / non-smokers $(\mathrm{N})$ & $7 / 12$ \\
\hline BDI-II score & $5.4 \pm 5.5$ \\
\hline STAl score (Trait anxiety) & $37.7 \pm 8.1$ \\
\hline Injected activity of [11C]carfentanil (MBq) & $252.2 \pm 10.8$ \\
\hline Injected activity of [11 C]raclopride (MBq) & $248.4 \pm 21.9$ \\
\hline
\end{tabular}

Image acquisition, quantification of receptor availability, and statistical analysis

We measured $\mu$-opioid receptor availability with the high-affinity agonist $\left[{ }^{11} \mathrm{C}\right]$ carfentanil (Frost et al., 1985) and $D_{2}$ receptor availability with the antagonist $\left[{ }^{11} \mathrm{C}\right]$ raclopride (Farde et al., 1986) using positron emission tomography (PET). Brain scans were performed before the start of the standard very low-calorie diet. Radiotracer production has been described previously (Karlsson et al., 2015). [ $\left.{ }^{11} \mathrm{C}\right]$ carfentanil and $\left[{ }^{11} \mathrm{C}\right]$ raclopride scans were performed on separate days. Both radiotracers had high radiochemical purity (>99 $\%)$. Before scanning, a catheter was placed in the subject's left antecubital vein for tracer administration. Head was strapped to the scanner table in order to prevent head movement. Subjects fasted two hours prior to scanning. A CT scan was performed to serve as attenuation map. Clinical well-being of subjects were monitored during the scanning.

We injected both tracers as bolus $\left(252.2 \pm 10.8 \mathrm{MBq}\left[{ }^{11} \mathrm{C}\right]\right.$ carfentanil and $248.4 \pm 21.9 \mathrm{MBq}\left[{ }^{11} \mathrm{C}\right]$ raclopride $)$. After the injection, radioactivity in brain was measured with the GE Heatlhcare Discovery ${ }^{\mathrm{TM}} 690$ PET/CT scanner (General Electric Medical Systems, Milwaukee, WI, USA) for 51 minutes, using 13 time frames. MR imaging was performed with Philips Gyroscan Intera 1.5 T CV Nova Dual scanner to exclude structural abnormalities and to provide anatomical reference images for the PET scans. High-resolution anatomical images ( $1 \mathrm{~mm}^{3}$ voxel size) were acquired using a T1-weighted sequence (TR $25 \mathrm{~ms}$, TE $4.6 \mathrm{~ms}$, flip angle $30^{\circ}$, scan time $376 \mathrm{~s})$. 
medRxiv preprint doi: https://doi.org/10.1101/2021.01.27.21250121; this version posted January $31,2021$. The copyright holder for this preprint (which was not certified by peer review) is the author/funder, who has granted medRxiv a license to display the preprint in

All rights reserved. No reuse allowed without permission.

All alignment and coregistration steps were performed using SPM8 software (www.fil.ion.ucl.ac.uk/spm/) running on Matlab R2012a (The Mathworks Inc., Sherborn, Massachusetts). To correct for head motion, dynamic PET images were first realigned frame-to-frame. The individual T1-weighted MR images were coregistered to the summation images calculated from the realigned frames. Regions of interest (ROls) for reference regions were drawn manually on MRI images using PMOD 3.4 software (PMOD Technologies Ltd., Zurich, Switzerland). Occipital cortex was used as the reference region for $\left[{ }^{11} \mathrm{C}\right]$ carfentanil and cerebellum for $\left[{ }^{11} \mathrm{C}\right]$ raclopride. Receptor availability was expressed in terms of $B P_{\mathrm{ND}}$, which is the ratio of specific to nondisplaceable binding in brain. $B P_{N D}$ was calculated applying basis function method for each voxel using the simplified reference tissue model (SRTM) with reference tissue time activity curves (TAC) as input data (Gunn et al., 1997).

The subject-wise parametric $B P_{\mathrm{ND}}$ images were normalized to the MNI space using the T1-weighted MR images, and smoothed with a Gaussian kernel of $8 \mathrm{~mm}$ FWHM. Anatomic regions of interest were generated in ventral striatum, dorsal caudate nucleus, and putamen using the AAL (Tzourio-Mazoyer et al., 2002) and Anatomy (Eickhoff et al., 2005) toolboxes. Regional $\left[{ }^{11} \mathrm{C}\right]$ carfentanil and $\left[{ }^{11} \mathrm{C}\right]$ raclopride binding potentials $\left(B P_{N D}\right)$ were extracted and correlated with subject weights at 3, 6, 12, and 24 months after surgery. Moreover, $\mathrm{BDI}$ and STAI scores were correlated with $\left[{ }^{11} \mathrm{C}\right]$ carfentanil and $\left[{ }^{11} \mathrm{C}\right]$ raclopride binding potentials as well as subject weight at different time points.

\section{Results}

Mean MOR availability in the subjects is presented in Figure 1. Mean weight loss at 3 months was $20.8 \pm 5.6$ $\mathrm{kg}$, at 6 months was $25.7 \pm 7.7 \mathrm{~kg}$, at 12 months was $28.3 \pm 12.1 \mathrm{~kg}$, and at 24 months was $30.7 \pm 15.1 \mathrm{~kg}$. Postoperative weight development is shown in the Figure 2.

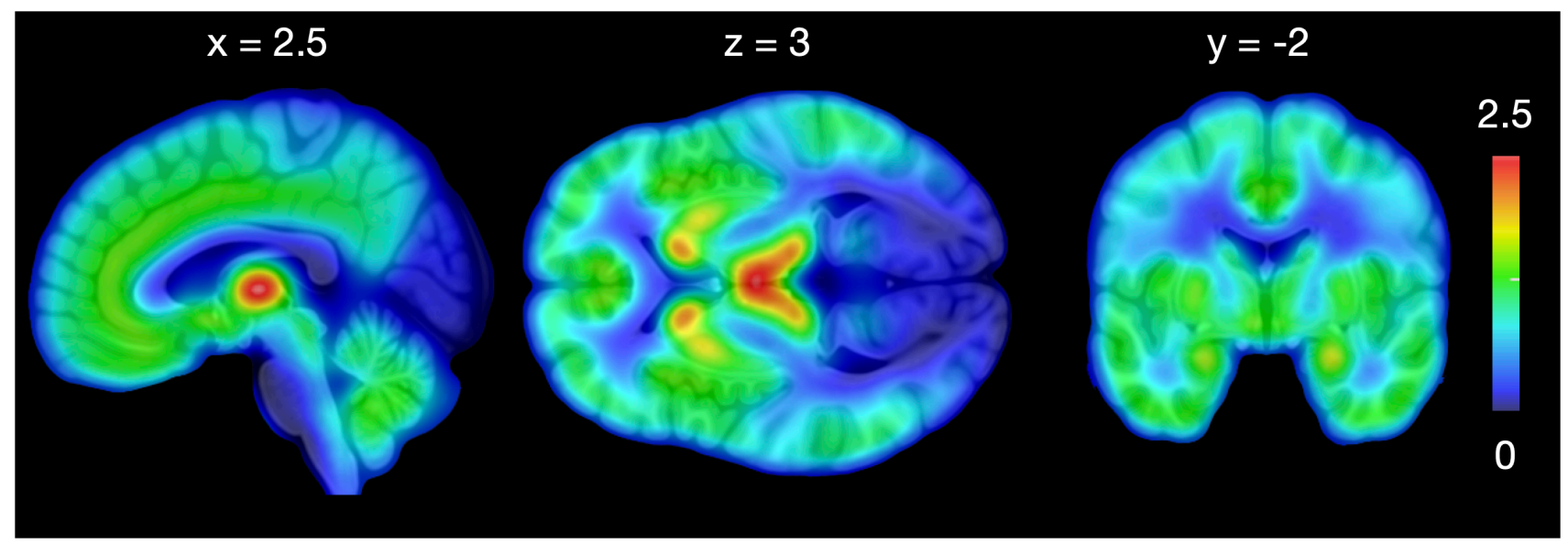

Figure 1: Mean $\left[{ }^{11} \mathrm{C}\right]$ carfentanil $B P_{\mathrm{ND}}$ in morbidly obese subjects before surgery. 
medRxiv preprint doi: https://doi.org/10.1101/2021.01.27.21250121; this version posted January 31, 2021. The copyright holder for this preprint (which was not certified by peer review) is the author/funder, who has granted medRxiv a license to display the preprint in All rights reserved. No reuse allowed without permission.

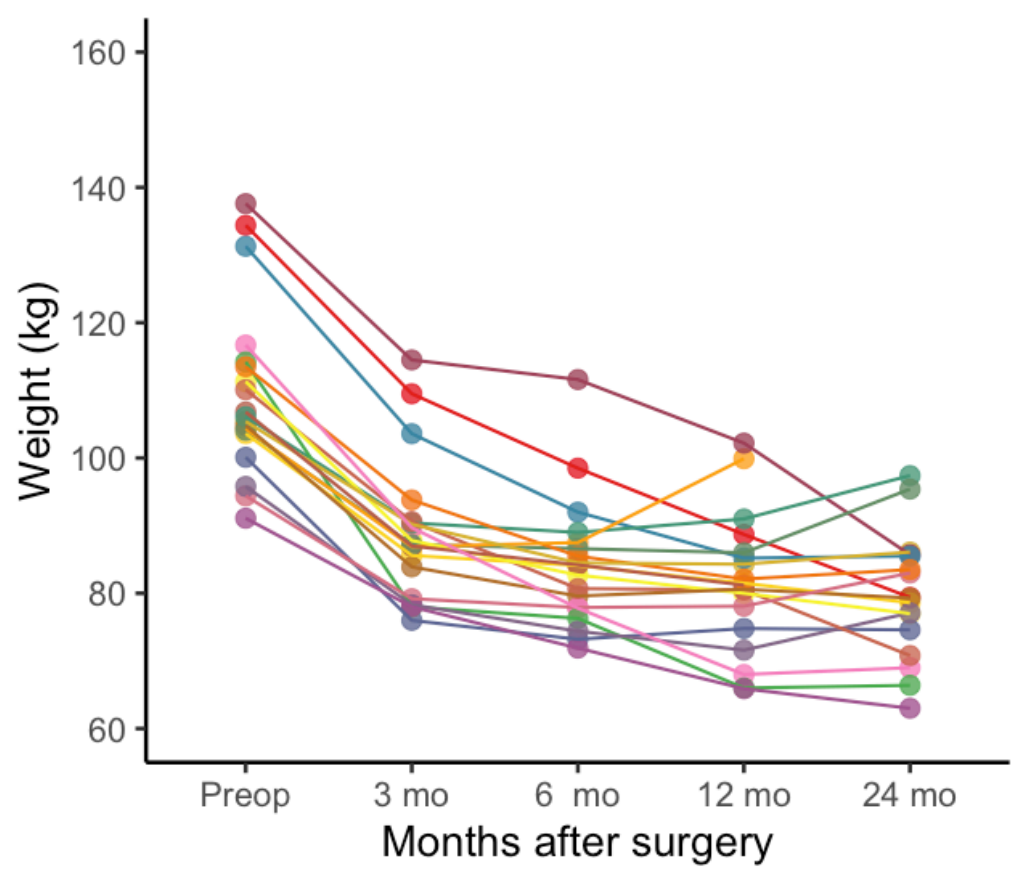

Figure 2: Weight development after bariatric surgery for each subject. Two subjects discontinued the study before 24 months follow-up visit.

Preoperative MOR availabilities were significantly associated with the subject weight in the amygdala $(r=$ $0.54)$ (Figure 3), insula $(r=-0.46)$, ventral striatum $(r=-0.48)$ and putamen $(r=-0.49)$ at 3 months. Significant association was also found in the amygdala at 6 months $(r=-0.53)$ and at 12 months $(r=-0.49)$ (Figure 3). Moreover, significant association was observed in the amygdala $(r=-0.50)$ (Figure 2) and thalamus at 24 months $(r s<-0.49)$.

Preoperative weight did not correlate with MOR availabilities in any brain area. We did not find any significant correlation between preoperative $D_{2} R$ availability and subject weight in any brain area at any time point. No significant correlations between $\mathrm{BDI}-\mathrm{II}$ and STAI scores and MOR and $\mathrm{D}_{2} \mathrm{R}$ availabilities in any brain area were observed. BDI-II and STAI scores did not predict weight loss at any time point. 

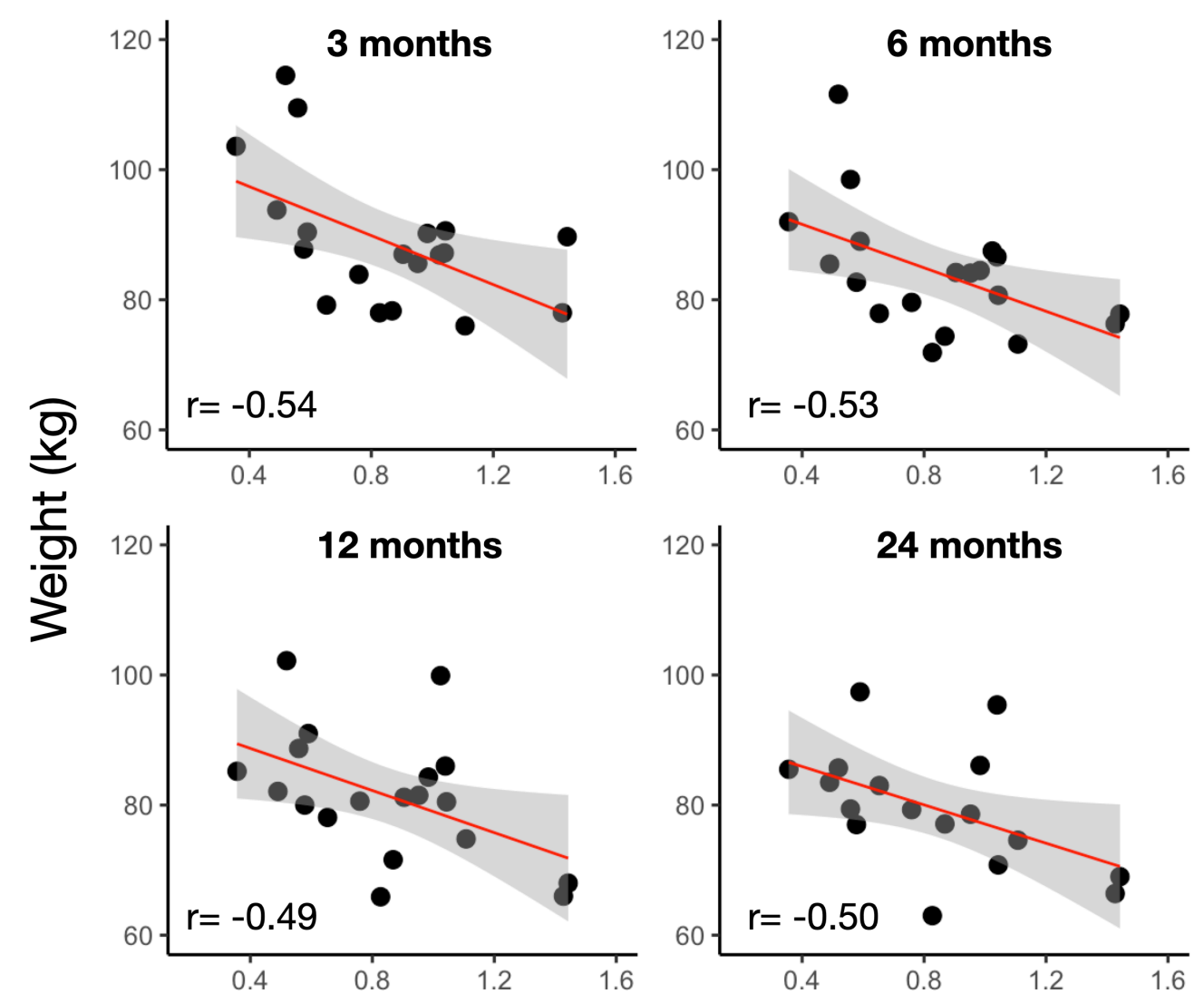

[11C]carfentanil $\mathrm{BP}_{\mathrm{ND}}$ in amygdala

Figure 3: Correlations between preoperative $\left[{ }^{11} \mathrm{C}\right]$ carfentanil $B P_{\mathrm{ND}}$ in amygdala and subject weight at 3, 6, 12, and 24 months.

\section{Discussion}

Our main finding was that neuroimaging markers predict the weight loss outcome after bariatric surgery. MOR availability in the amygdala consistently predicted weight development throughout the 24-month follow-up period, even though MOR availability was not initially associated with preoperative weight. No associations were found for $D_{2} R$. These results show that neuromolecular phenotypes may contribute to the outcome of weight loss after bariatric surgery, possibly providing novel predictive biomarkers for postoperative weight loss after bariatric surgery.

Obesity is expensive for the society, especially due to the obesity related comorbidities. Bariatric surgery reduces mean costs to the health service compared with usual care (Borisenko et al., 2018). However, a significant number of the patients experience weight regain (Monaco-Ferreira and Leandro-Merhi, 2017), which was also seen in our study (Figure 2). Determining patient characteristics leading to sustainable weight loss at long-term is important, but so far there have not been reliable markers. Some metabolic markers may 
medRxiv preprint doi: https://doi.org/10.1101/2021.01.27.21250121; this version posted January $31,2021$. The copyright holder for this preprint (which was not certified by peer review) is the author/funder, who has granted medRxiv a license to display the preprint in perpetuity.

All rights reserved. No reuse allowed without permission.

predict weight regain after surgery (Abidi et al., 2019), also taste preference towards salty or sucrosesweetened foods may contribute to some extent (Zhang et al., 2019; Smith et al., 2020). Our study is the first PET study to predict the outcome of bariatric surgery from neuroimaging markers, and only two small MRI studies exist (Holsen et al., 2018; Cerit et al., 2019). Our study shows that molecular organization of the brain's reward circuit is an important determinant of the surgery-induced weight loss.

Bariatric surgery alleviates depressive and anxious symptoms (Dawes et al., 2016; Gill et al., 2019), yet psychiatric comorbidities are associated with weight gain following surgery (Mauro et al., 2019; Muller et al., 2019). Surgery has a more positive impact on the depressive disorders than anxiety disorders (de Zwaan et al., 2011), but preoperative symptoms also likely affect the results of the surgical methods. Preoperative depression is also associated with lower postoperative weight loss (Pedro et al., 2020). Although MOR availability is associated with depressive and anxious symptoms (Nummenmaa et al., 2020), we observed no association between depressive and anxiety symptoms and weight loss. This may be due to low statistical power for the questionnaire-based measures, as well as relative crudeness of questionnaires (in comparison with structural interviews such as MADRS).

Human PET studies have shown that feeding activates the endogenous opioid system (Tuulari et al., 2017), and consequently dysfunction of the endogenous opioid system is a key component underlying overeating, and thus a feasible target for pharmacological and behavioural interventions. Previous studies have investigated effects of bariatric surgery and following weight loss to separate receptor systems, showing mainly unaltered $D_{2} R$ availability and normalized MOR availability (Dunn et al., 2010; Steele et al., 2010; de Weijer et al., 2014; Karlsson et al., 2016), although one animal study has yielded contradictory findings (Hankir et al., 2016). Our study highlights the importance of MOR in the amygdala in predicting the weight management after the surgery. Opioidergic circuits in the amygdala are critical for emotions including fear and anxiety (Nummenmaa and Tuominen, 2018), but it is also one of the key regions in appetite control (Adhikari et al., 2015). MOR availability in amygdala is associated with subclinical depressive and anxiety symptoms (Nummenmaa et al., 2020), and it is likely that individual differences in MOR availability also in the amygdala may explain the differences in eating behaviour (Nummenmaa et al., 2018). It has also been shown that bariatric surgery can recover initially downregulated MOR in the amygdala of obese patients (Karlsson et al., 2016).

Our study has several limitations. Only female subjects were studied, and the results may not be generalizable to male subjects. Sample size was limited, possibly precluding establishing associations between MOR availabilities, weight development, and preoperative psychiatric symptoms. We followed the subjects only for 
medRxiv preprint doi: https://doi.org/10.1101/2021.01.27.21250121; this version posted January $31,2021$. The copyright holder for this preprint (which was not certified by peer review) is the author/funder, who has granted medRxiv a license to display the preprint in perpetuity.

All rights reserved. No reuse allowed without permission.

two years as part of their standard clinical visits, but longer follow-up might have showed different trajectories. However, longer follow-up studies are planned in the future (Vreeken et al., 2019).

In summary, preoperative MOR availability in the amygdala predicts weight outcomes after bariatric surgery. Postoperative weight regain or primary weight loss failure may partially depend on dysfunctional opioid system. There is growing evidence that opioidergic system plays an important role in governing multitude of reward functions (Nummenmaa et al., 2018), and this study further confirmed its significance in the aspects of feeding (Tuulari et al., 2017). Downregulation of the MOR system can be reversed by surgical (Karlsson et al., 2016) and non-surgical weight loss (Burghardt et al., 2015). The present study extended these findings by establishing the role of MOR in long-term weight maintenance. Future prospective studies should address whether MOR availability is also predicative of weight gain in normal-weight subjects, and whether it predicts weight loss success by conventional dieting-based approaches.

\section{References}

Abidi W, Nestoridi E, Feldman H, Stefater M, Clish C, Thompson CC, Stylopoulos N (2019) Differential Metabolomic Signatures in Patients with Weight Regain and Sustained Weight Loss After Gastric Bypass Surgery: A Pilot Study.

Adams TD, Davidson LE, Litwin SE, Kim J, Kolotkin RL, Nanjee MN, Gutierrez JM, Frogley SJ, Ibele AR, Brinton EA, Hopkins PN, McKinlay R, Simper SC, Hunt SC (2017) Weight and Metabolic Outcomes 12 Years after Gastric Bypass. The New England journal of medicine 377:1143-1155.

Adhikari A, Lerner TN, Finkelstein J, Pak S, Jennings JH, Davidson TJ, Ferenczi E, Gunaydin LA, Mirzabekov JJ, Ye L, Kim SY, Lei A, Deisseroth K (2015) Basomedial amygdala mediates top-down control of anxiety and fear. Nature 527:179-185.

Baig SJ, Priya P, Mahawar KK, Shah S (2019) Weight Regain After Bariatric Surgery-A Multicentre Study of 9617 Patients from Indian Bariatric Surgery Outcome Reporting Group. Obesity surgery 29:15831592.

Beck A, Steer R, Brown G (1996) Manual for the Beck Depression Inventory-II. San Antonio, TX: Psychological Corporation.

Borisenko O, Lukyanov V, Ahmed AR (2018) Cost-utility analysis of bariatric surgery. The British journal of surgery 105:1328-1337.

Brethauer SA, Kim J, el Chaar M, Papasavas P, Eisenberg D, Rogers A, Ballem N, Kligman M, Kothari S (2015) Standardized outcomes reporting in metabolic and bariatric surgery. Surgery for obesity and related diseases : official journal of the American Society for Bariatric Surgery 11:489-506.

Burghardt PR, Rothberg AE, Dykhuis KE, Burant CF, Zubieta JK (2015) Endogenous Opioid Mechanisms Are Implicated in Obesity and Weight Loss in Humans. J Clin Endocrinol Metab 100:3193-3201.

Cambridge VC, Ziauddeen H, Nathan PJ, Subramaniam N, Dodds C, Chamberlain SR, Koch A, Maltby K, Skeggs AL, Napolitano A, Faroogi IS, Bullmore ET, Fletcher PC (2013) Neural and behavioral effects of a novel mu opioid receptor antagonist in binge-eating obese people. Biological psychiatry 73:887894. 
medRxiv preprint doi: https://doi.org/10.1101/2021.01.27.21250121; this version posted January $31,2021$. The copyright holder for this preprint (which was not certified by peer review) is the author/funder, who has granted medRxiv a license to display the preprint in perpetuity.

All rights reserved. No reuse allowed without permission.

Cerit H, Davidson P, Hye T, Moondra P, Haimovici F, Sogg S, Shikora S, Goldstein JM, Evins AE, WhitfieldGabrieli S, Stoeckel LE, Holsen LM (2019) Resting-State Brain Connectivity Predicts Weight Loss and Cognitive Control of Eating Behavior After Vertical Sleeve Gastrectomy. Obesity (Silver Spring, Md) 27:1846-1855.

Cooper TC, Simmons EB, Webb K, Burns JL, Kushner RF (2015) Trends in Weight Regain Following Rouxen-Y Gastric Bypass (RYGB) Bariatric Surgery. Obesity surgery.

Courcoulas AP, King WC, Belle SH, Berk P, Flum DR, Garcia L, Gourash W, Horlick M, Mitchell JE, Pomp A, Pories WJ, Purnell JQ, Singh A, Spaniolas K, Thirlby R, Wolfe BM, Yanovski SZ (2018) Seven-Year Weight Trajectories and Health Outcomes in the Longitudinal Assessment of Bariatric Surgery (LABS) Study. JAMA surgery 153:427-434.

Dawes AJ, Maggard-Gibbons M, Maher AR, Booth MJ, Miake-Lye I, Beroes JM, Shekelle PG (2016) Mental Health Conditions Among Patients Seeking and Undergoing Bariatric Surgery: A Meta-analysis. JAMA : the journal of the American Medical Association 315:150-163.

de Weijer BA, van de Giessen E, Janssen I, Berends FJ, van de Laar A, Ackermans MT, Fliers E, la Fleur SE, Booij J, Serlie MJ (2014) Striatal dopamine receptor binding in morbidly obese women before and after gastric bypass surgery and its relationship with insulin sensitivity. Diabetologia 57:1078-1080.

de Zwaan M, Enderle J, Wagner S, Mühlhans B, Ditzen B, Gefeller O, Mitchell JE, Müller A (2011) Anxiety and depression in bariatric surgery patients: a prospective, follow-up study using structured clinical interviews. Journal of affective disorders 133:61-68.

Dunn JP, Cowan RL, Volkow ND, Feurer ID, Li R, Williams DB, Kessler RM, Abumrad NN (2010) Decreased dopamine type 2 receptor availability after bariatric surgery: preliminary findings. Brain research 1350:123-130.

Eickhoff SB, Stephan KE, Mohlberg H, Grefkes C, Fink GR, Amunts K, Zilles K (2005) A new SPM toolbox for combining probabilistic cytoarchitectonic maps and functional imaging data. Neurolmage 25:13251335.

Farde L, Hall H, Ehrin E, Sedvall G (1986) Quantitative analysis of D2 dopamine receptor binding in the living human brain by PET. Science (New York, NY) 231:258-261.

Fields HL, Margolis EB (2015) Understanding opioid reward. Trends in neurosciences.

Frost JJ, Wagner HN, Jr., Dannals RF, Ravert HT, Links JM, Wilson AA, Burns HD, Wong DF, McPherson RW, Rosenbaum AE, et al. (1985) Imaging opiate receptors in the human brain by positron tomography. Journal of computer assisted tomography 9:231-236.

Gill H, Kang S, Lee Y, Rosenblat JD, Brietzke E, Zuckerman H, Mclntyre RS (2019) The long-term effect of bariatric surgery on depression and anxiety. Journal of affective disorders 246:886-894.

Gunn RN, Lammertsma AA, Hume SP, Cunningham VJ (1997) Parametric imaging of ligand-receptor binding in PET using a simplified reference region model. Neurolmage 6:279-287.

Hankir MK, Patt M, Patt JT, Becker GA, Rullmann M, Kranz M, Deuther-Conrad W, Schischke K, Seyfried F, Brust P, Hesse S, Sabri O, Krugel U, Fenske WK (2016) Suppressed Fat Appetite after Roux-en-Y Gastric Bypass Surgery Associates with Reduced Brain mu-opioid Receptor Availability in DietInduced Obese Male Rats. Frontiers in neuroscience 10:620.

Holsen LM, Davidson P, Cerit H, Hye T, Moondra P, Haimovici F, Sogg S, Shikora S, Goldstein JM, Evins AE, Stoeckel LE (2018) Neural predictors of 12-month weight loss outcomes following bariatric surgery. International journal of obesity (2005) 42:785-793.

Karlsson HK, Tuominen L, Tuulari JJ, Hirvonen J, Parkkola R, Helin S, Salminen P, Nuutila P, Nummenmaa L (2015) Obesity is associated with decreased $\mu$-opioid but unaltered dopamine D2 receptor availability in the brain. The Journal of neuroscience : the official journal of the Society for Neuroscience 35:39593965.

Karlsson HK, Tuulari JJ, Tuominen L, Hirvonen J, Honka H, Parkkola R, Helin S, Salminen P, Nuutila P, Nummenmaa $L$ (2016) Weight loss after bariatric surgery normalizes brain opioid receptors in morbid obesity. Molecular psychiatry 21:1057-1062. 
medRxiv preprint doi: https://doi.org/10.1101/2021.01.27.21250121; this version posted January $31,2021$. The copyright holder for this preprint (which was not certified by peer review) is the author/funder, who has granted medRxiv a license to display the preprint in perpetuity.

All rights reserved. No reuse allowed without permission.

Mauro M, Papelbaum M, Brasil MAA, Carneiro JRI, Coutinho ESF, Coutinho W, Appolinario JC (2019) Is weight regain after bariatric surgery associated with psychiatric comorbidity? A systematic review and meta-analysis. Obesity reviews : an official journal of the International Association for the Study of Obesity 20:1413-1425.

Monaco-Ferreira DV, Leandro-Merhi VA (2017) Weight Regain 10 Years After Roux-en-Y Gastric Bypass. Obesity surgery 27:1137-1144.

Muller M, Nett PC, Borbely YM, Buri C, Stirnimann G, Laederach K, Kroll D (2019) Mental Illness Has a Negative Impact on Weight Loss in Bariatric Patients: a 4-Year Follow-up. Journal of gastrointestinal surgery : official journal of the Society for Surgery of the Alimentary Tract 23:232-238.

Nathan PJ, O'Neill BV, Bush MA, Koch A, Tao WX, Maltby K, Napolitano A, Brooke AC, Skeggs AL, Herman CS, Larkin AL, Ignar DM, Richards DB, Williams PM, Bullmore ET (2012) Opioid receptor modulation of hedonic taste preference and food intake: a single-dose safety, pharmacokinetic, and pharmacodynamic investigation with GSK1521498, a novel mu-opioid receptor inverse agonist. Journal of clinical pharmacology 52:464-474.

Nummenmaa L, Tuominen L (2018) Opioid system and human emotions. British journal of pharmacology 175:2737-2749.

Nummenmaa L, Saanijoki T, Tuominen L, Hirvonen J, Tuulari JJ, Nuutila P (2018) mu-opioid receptor system mediates reward processing in humans. 9:1500.

Nummenmaa L, Karjalainen T, Isojärvi J, Kantonen T, Tuisku J, Kaasinen V, Joutsa J, Nuutila P, Kalliokoski K, Hirvonen J, Hietala J, Rinne J (2020) Lowered endogenous mu-opioid receptor availability in subclinical depression and anxiety. Neuropsychopharmacology : official publication of the American College of Neuropsychopharmacology.

Odom J, Zalesin KC, Washington TL, Miller WW, Hakmeh B, Zaremba DL, Altattan M, Balasubramaniam M, Gibbs DS, Krause KR, Chengelis DL, Franklin BA, McCullough PA (2010) Behavioral predictors of weight regain after bariatric surgery. Obesity surgery 20:349-356.

Pecina S, Smith KS (2010) Hedonic and motivational roles of opioids in food reward: implications for overeating disorders. Pharmacology, biochemistry, and behavior 97:34-46.

Pedro J, Neves JS, Ferreira MJ, Guerreiro V, Salazar D, Viana S, Mendonça F, Silva MM, Brandão I, Belo S, Freitas P, Varela A, Carvalho D (2020) Impact of Depression on Weight Variation after Bariatric Surgery: A Three-Year Observational Study. Obesity facts 13:213-220.

Salamone JD, Correa M (2013) Dopamine and food addiction: lexicon badly needed. Biological psychiatry 73:e15-24.

Salminen P (2018) Standardized Uniform Reporting and Indications for Bariatric and Metabolic Surgery: How Can We Reach This Goal? JAMA surgery 153:1077-1078.

Sarwer DB, Allison KC, Wadden TA, Ashare R, Spitzer JC, McCuen-Wurst C, LaGrotte C, Williams NN, Edwards M, Tewksbury C, Wu J (2019) Psychopathology, disordered eating, and impulsivity as predictors of outcomes of bariatric surgery. Surgery for obesity and related diseases : official journal of the American Society for Bariatric Surgery 15:650-655.

Schauer PR, Bhatt DL, Kirwan JP, Wolski K, Aminian A, Brethauer SA, Navaneethan SD, Singh RP, Pothier CE, Nissen SE, Kashyap SR (2017) Bariatric Surgery versus Intensive Medical Therapy for Diabetes 5-Year Outcomes. The New England journal of medicine 376:641-651.

Shantavasinkul PC, Omotosho P, Corsino L, Portenier D, Torquati A (2016) Predictors of weight regain in patients who underwent Roux-en-Y gastric bypass surgery. Surgery for obesity and related diseases : official journal of the American Society for Bariatric Surgery 12:1640-1645.

Smith KR, Papantoni A, Veldhuizen MG, Kamath V, Harris C, Moran TH, Carnell S, Steele KE (2020) Tasterelated reward is associated with weight loss following bariatric surgery. The Journal of clinical investigation 130:4370-4381.

Spielberger C, Gorsuch R, Lushene R, Vagg P, Jacobs G (1983) Manual for the State-Trait Anxiety Inventory. Palo Alto, CA: Consulting Psychologists Press. 
medRxiv preprint doi: https://doi.org/10.1101/2021.01.27.21250121; this version posted January $31,2021$. The copyright holder for this preprint (which was not certified by peer review) is the author/funder, who has granted medRxiv a license to display the preprint in

All rights reserved. No reuse allowed without permission.

Steele KE, Prokopowicz GP, Schweitzer MA, Magunsuon TH, Lidor AO, Kuwabawa H, Kumar A, Brasic J, Wong DF (2010) Alterations of central dopamine receptors before and after gastric bypass surgery. Obesity surgery 20:369-374.

Stice E, Yokum S, Burger KS, Epstein LH, Small DM (2011) Youth at risk for obesity show greater activation of striatal and somatosensory regions to food. The Journal of neuroscience : the official journal of the Society for Neuroscience 31:4360-4366.

Tuulari JJ, Tuominen L, de Boer FE, Hirvonen J, Helin S, Nuutila P, Nummenmaa L (2017) Feeding Releases Endogenous Opioids in Humans. J Neurosci 37:8284-8291.

Tzourio-Mazoyer N, Landeau B, Papathanassiou D, Crivello F, Etard O, Delcroix N, Mazoyer B, Joliot M (2002) Automated anatomical labeling of activations in SPM using a macroscopic anatomical parcellation of the MNI MRI single-subject brain. Neurolmage 15:273-289.

Volkow ND, Wang GJ, Telang F, Fowler JS, Thanos PK, Logan J, Alexoff D, Ding YS, Wong C, Ma Y, Pradhan K (2008) Low dopamine striatal D2 receptors are associated with prefrontal metabolism in obese subjects: possible contributing factors. Neurolmage 42:1537-1543.

Voorwinde V, Steenhuis IHM, Janssen IMC, Monpellier VM, van Stralen MM (2020) Definitions of Long-Term Weight Regain and Their Associations with Clinical Outcomes. Obesity surgery 30:527-536.

Vreeken D, Wiesmann M, Deden LN, Arnoldussen IAC, Aarts E, Kessels RPC, Kleemann R, Hazebroek EJ, Aarts EO, Kiliaan AJ (2019) Study rationale and protocol of the BARICO study: a longitudinal, prospective, observational study to evaluate the effects of weight loss on brain function and structure after bariatric surgery. BMJ open 9:e025464.

Zhang Y, Nagarajan N, Portwood C, Smith KR, Kamath V, Carnell S, Moran TH, Steele KE (2019) Does taste preference predict weight regain after bariatric surgery? Surgical endoscopy. 